\title{
Von Balthasar: Teólogo em diálogo com a cultura
}

Renato Vieira

\section{Resumo}

Este artigo procura tematizar a pessoa e a teologia do teólogo suíço Hans Urs Von Balthasar, mostrando o seu profundo desejo de dialogar com a cultura, a fim de dar as razões da fé cristã a todos. Após uma pequena nota biográfica, se busca apresentar os pontos relevantes da teologia balthasariana, para finalmente, apresentar de um modo esquemático, a obra magna de Balthasar, a saber, a sua trilogia do amor, onde utilizando criativamente os transcendentais do belo, do bom e do verdadeiro, ele tenta mostrar Deus a partir da Revelação como aquele que se mostra, se dá e se diz. De mais a mais, não se pode esquecer o papel fundamental que tem a noção de santidade na teologia balthasariana no seu diálogo com o mundo e a cultura.

Palavras-chave: Balthasar, Teologia, Santidade, Cultura.

\section{Abstract}

This paper seeks to thematize the person and theology of the Swiss theologian Hans Urs von Balthasar, showing his deep desire to dialogue with the culture in order to give the reasons of the Christian faith to everyone. After a short biographical note, it seeks to present relevant points of balthasarian's 
theology to finally present, in a schematic way, the magnum opus of Balthasar, namely, his trilogy of love, where creatively using the transcendental of beauty, good and true, he tries to show from God's revelation as the one who shows itself, gives it self and says itself. Moreover, we can not forget the fundamental role that has the notion of holiness balthasarian's theology in its dialogue with the world and culture.

Keywords: Balthasar, Theology, Holiness, Culture.

\section{Introdução}

O cardeal suíço Hans Urs Von Balthasar foi um grande teólogo. Reverenciado por João Paulo II e homem de extraordinária cultura, ele buscou incansavelmente, ao longo de toda a sua obra, estabelecer um frutuoso diálogo com a cultura de seu tempo, a fim de mostrar a relevância da fé e do cristianismo para o ser humano.

Com o modesto objetivo de apresentar Balthasar e sua obra para todos aqueles que ainda não o conhecem, este artigo está dividido em três partes. $\mathrm{Na}$ primeira se verá uma sucinta biografia de Balthasar, com ênfase nas pessoas, momentos e lugares mais importantes. Em seguida, na segunda parte, serão apresentadas algumas características fundamentais da teologia balthasariana para que finalmente, se possa falar, ainda que de modo sumário, da obra magna de Balthasar.

Deseja-se com este artigo, despertar o leitor para a importância de Balthasar e para a profundidade da sua teologia, que está condensada na sua famosa trilogia: Glória, Teodramática e Teológica, obra que alguns até consideram ser uma verdadeira "suma teológica" para os tempos atuais. ${ }^{1}$

\section{Pequena biografia de Balthasar}

Em Balthasar vida e obra estão unidas tão visceralmente que é quase impossível separá-las. ${ }^{2}$ Isso faz jus ao estilo integrador do seu ser e do seu

\footnotetext{
${ }^{1}$ Ver, por exemplo, as palavras de Lima Vaz. Cf. VAZ, H. L. Unidade e diferença: linguagem e verdade na ciência e na fé. In: Revista Magis - caderno de fé e cultura Fé e ciência: duas linguagens para uma verdade, $\mathrm{n}^{\text {o. }} 18,1995$. PUC-RJ, p. 6. Disponível em pdf: <www.clfc.puc-rio.br/ pdf/fc18.pdf >, acessado dia 11 de outubro de 2011.

${ }^{2}$ Esse é o ponto de vista de Guerriero: “... publiquei uma monografia na qual me esforçava em
} 
pensar. Segundo Palumbo e Azcuy, vale para Balthasar a imagem musical que ele aplicou em um de seus escritos para o pluralismo cristão: "o pensamento de Balthasar é uma orquestração, na qual as diferentes melodias se interpenetram, de modo tal que 'a pluralidade de instrumentos que a compõem adquire sentido quando interpreta, sob a direção de Cristo, a sinfonia de Deus'".

Hans Urs von Balthasar nasceu em Lucerna, na Suíça, em 12 de agosto de 1905, no seio de uma família católica. Seu pai, Oskar foi um arquiteto famoso. Sua mãe, Gabrielle participou do movimento feminino católico. Tinha uma irmã, Renée, que se tornou freira e um irmão, Dieter, que se tornou oficial da guarda suíça.

O contexto em que cresce é cosmopolita e poliglota. Em criança é dotado de um extraordinário talento musical, de uma prodigiosa memória e de uma inteligência aguda e aberta. Depois de fazer o ginásio com os beneditinos de Engelberg, e o segundo grau com os jesuítas em Feldkirch, e vacilar durante algum tempo entre o estudo da música ou da literatura, Balthasar se inscreve em 1923 na Faculdade de Ciências Germânicas e Filosofia na Universidade de Mônaco.

Continua seus estudos em Viena e Berlim, onde conheceu Romano Guardini. Em 1928 concluiu seu doutorado em Zurique, obtendo nota máxima ao analisar a historia do problema escatológico, na moderna literatura alemã. No ano seguinte, após a morte de sua mãe Gabrielle, ingressa na Companhia de Jesus em Pullach.

A influência de Santo Inácio será determinante para a dimensão existencial da sua teologia. De 1929 a 1932, estuda filosofia e, em suas memórias, lembra-se deste tempo como uma travessia pelo deserto da neo-escolástica. Contudo, lá conheceu o Pe. Erich Pryzwara, SJ que o impressionou vivamente e o guiou na leitura de Agostinho e Santo Tomás.

Em seguida, vai para Fourvière, que fica perto de Lion, para fazer os estudos teológicos. Neste período, conhece o padre Henri de Lubac, SJ, que lhe transmite um vivo amor pelos Padres da Igreja. Também entra em contato com o rico mundo literário da França. É ordenado sacerdote em 26 de julho de 1936.

\footnotetext{
expor a biografia e a obra do teólogo em íntima correlação [...], ainda hoje estou convencido de que este seja o melhor modo de aproximar-se do pensamento de um teólogo que, como nenhum outro, visava dar uma cobertura existencial a suas afirmações". GUERRIERO, E. Hans Urs Von Balthasar. S. Paulo: Loyola, 2010, p. 15.

${ }^{3}$ Cf. PALUMBO, Cecília A. de e AZCUY, Virgínia R. Contornos de una figura. Introducción a Balthasar. In: Proyecto. 1998, p. 7-23.
} 
Diante da alternativa de ser professor em Roma ou ser capelão dos estudantes, Balthasar escolhe essa última e em 1940 vai para Basiléia, onde faz amizade com o grande teólogo evangélico Karl Barth, com quem partilhava um grande amor pela música de Mozart. Nesta mesma cidade encontra Adrienne Von Spyer $(* 1902+1967)$ que será batizada por ele no primeiro dia de novembro de 1940. Será seu diretor espiritual e acompanhará suas experiências místicas. Junto com ela fundará a comunidade São João em 1945 e a editora São João em 1947. Interessante notar que estas fundações se realizam no horizonte da espiritualidade do evangelista João, a partir de uma releitura teológica do Cristianismo, tendo por centro a vivencia dos conselhos evangélicos no mundo.

Como em 1950 não conseguiu que a Companhia de Jesus assumisse e fizesse própria essa obra, deixa os jesuítas. Ele tinha a convicção de que recebia de Deus um novo chamado. A sua escolha não foi compreendida por muitos. Viveu um tempo de isolamento e se dedicou à obra começada, recusando até mesmo a cátedras universitárias.

No ano de 1956, Balthasar é incardinado na diocese de Coira. Fixa sua residência em Basiléia. Não foi convidado a participar do Concílio, o que para De Lubac foi algo "desconcertante e humilhante". Neste período, começa a escrever sua obra magna, a Trilogia do amor, que consumiu 25 anos da sua vida. Aos poucos, Balthasar foi saindo do esquecimento.

Paulo VI o convida em 1969, para participar da Comissão teológica internacional que estava sendo fundada, e na qual permaneceu até a morte. Em 1971, foi o secretário do Sínodo dos bispos da Alemanha. Em 1972, funda com o então sacerdote e professor Joseph Ratzinger e outros, a revista Communio. Em 1984, recebe das mãos de João Paulo II o prêmio internacional Paulo VI. João Paulo II o nomeia cardeal em 1988.

Na manhã de 26 de junho do mesmo ano, dois dias antes do consistório em que seria criado cardeal, Balthasar morre em Basiléia aos 83 anos de idade, dos quais 65 foram dedicados a uma copiosa obra teológica que ainda não foi suficientemente explorada. ${ }^{4}$

\section{A teologia de Balthasar}

Balthasar foi um homem fascinado pela glória de Deus. Sua vida e seu pensamento querem ser nada mais do que um simples fragmento onde possa

${ }^{4}$ Uma excelente biografia de Balthasar traduzida para o português é a de Elio GUERRIERO. Cf.: Hans Urs Von Balthasar. São Paulo: Loyola, 2010. 
resplandecer para todos a beleza do Deus de Jesus Cristo. ${ }^{5}$ Para ele, só uma teologia bela pode ser uma teologia eficaz. ${ }^{6}$

\section{1 "Deus semper major"}

Balthasar não elaborou uma teologia sistemática. ${ }^{7}$ Segundo Scola, Balthasar tinha a consciência de que era impossível para a razão humana abarcar a glória de Deus. ${ }^{8}$ Contudo, o ser humano pode experimentar Deus e pensar Deus pela via da santidade. Na teologia de Balthasar se percebe a contínua preocupação em relacionar teologia e santidade ${ }^{9}$, entendida como abertura total do espírito à Revelação divina. ${ }^{10}$ Trata-se da adoração que nasce em quem compreende racionalmente que o Mistério divino é incompreensível. Claro que essa posição não justifica uma "preguiça" teológica. De fato, antes do silêncio reverente, é necessário o estudo paciente. Aqui o sentido é de um Mistério que é inesgotável. ${ }^{11}$ É como um poço que quanto mais se tenta esvaziar,

\footnotetext{
${ }^{5}$ SCOLA, A. Hans Urs Von Balthasar: um estilo teológico. Madrid: Encuentro, 1997, p. 18.

${ }^{6}$ Diz Balthasar que “... Sólo una teologia bella, o sea, una teologia que, alcanzada por la gloria Dei, logra a su vez hacerla resplandecer, tiene la possibilidad de incidir en la historia de los hombres, impresionándola y transformándola”. Cf. Gloria, vol. II, p. 15.

${ }^{7} \mathrm{~A}$. Meis defende a idéia de que existe uma sistemática no pensamento de Balthasar a partir da figura de Cristo que é a forma que dá unidade aos fragmentos do ser, pois a Encarnação significa a inclusão da totalidade na singularidade. Cf. MEIS, A. Hans Urs Von balthasar. Un teólogo católico sistemático. In: VV.AA. Grandes teólogos del siglo XX. Santiago: San Pablo, 1996, 39-74. Vale lembrar que Balthasar nunca foi professor, apesar dos convites, e por isso, não se preocupava em elaborar esquemas que facilitassem a compreensão dos alunos.

${ }^{8}$ Scola, A. Hans Urs Von Balthasar: um estilo teológico. Madrid: Encuentro, 1997, p. 17.

${ }^{9}$ Há um escrito muito famoso de Balthasar sobre esse tema: Teologia e santidade, In: BALTHASAR, Verbum Caro, Ensayos teológicos, vol. I. Ali se encontra a conhecida contraposição entre uma teologia ajoelhada e uma teologia sentada. Scola explica que “...estar de rodillas no tiene nada que ver com manifestaciones pietistas que sustituyan el rigor científico - el cual únicamente puede nacer de la larga y fatigosa familiaridad con el estúdio y la investigación -, sino con la posición del corazón del teólogo que es la de Pablo en él camino de Damasco.... Cf. SCOLA, A. Hans Urs Von Balthasar: um estilo teológico. Madrid: Encuentro, 1997, p. 16.

${ }^{10}$ FISICHELLA, R. Balthasar. In: LACOSTE, J.-Y. (dir.). Dicionário Crítico de Teologia. São Paulo: Loyola, 2004, pp. 231-237.

${ }^{11}$ Para Balthasar a teologia deve ser humilde, pois seu objeto sempre lhe escapa por ser divino: "A verdade da Revelação, por ser verdade divina e vivida, está constituída de tal forma que a teologia (...) tem que permitir que seu conteúdo de verdade seja medido pela adoração e a obediência. Pois Cristo não é uma teoria: não o é tão pouco enquanto Verdade. E uma teoria sobre Cristo deve se deixar medir e orientar pela Verdade, à maneira como Cristo é a Verdade (e não à maneira como as ciências do mundo são verdadeiras)". Cf. BALTHASAR, Verbum Caro. Ensayos teológicos, vol. I, Madrid: Encuentro, p. 163.
} 
mais água tem. "Revelando-se o mistério segue misterioso, e toda a inteligência da fé se embasa, antes de tudo, em uma fé simples, que abarca muito mais do que compreende, porque crê em Deus", diz Balthasar. ${ }^{12} \mathrm{Em}$ poucas palavras, se pode conhecer a Deus mais profundamente, mas tal conhecimento nunca esgota a grandeza infinita de Deus; por outras, o teólogo sabe que Deus é infinito, mas isso não significa conhecê-1O infinitamente.

Diz Balthasar que:

a teologia verdadeira, a teologia dos santos, pergunta - obedecendo a fé, respeitando a caridade, e não perdendo jamais de vista o centro da Revelação - o que pensar, que modos de colocar os problemas, que vias intelectuais do homem são adequados para esclarecer o sentido da Revelação mesma. Este sentido não consiste de modo algum em transmitir ao homem conhecimentos abstrusos e ocultos, senão em uni-lo mais estreitamente com Deus, em vincular mais estreitamente com Deus sua existência inteira, também sua existência espiritual, intelectiva. ${ }^{13}$

Palumbo explica que não é fácil lidar com a teologia balthasariana, pois ela é uma tentativa de diálogo substancial com os clássicos da tradição cristã e com a verdade vivida dos santos. Para quem concebe a teologia somente como uma disciplina científica, de método rigoroso e forte racionalidade conceitua ${ }^{14}$, pode ser desafiadora a posição de Balthasar: "Devo dizer que, na realidade, só os santos me interessam como teólogos, desde Irineu até Anselmo e Boaventura, passando por Agostinho, ou figuras que irradiam santidade como um Dante ou um Newman, também se poderia nomear Kierkegaard e Soloviev" ${ }^{15}$

\footnotetext{
${ }^{12}$ BALTHASAR, H. El complejo antirromano, p. 236.

${ }^{13}$ BALTHASAR, H. Teologia y santidad. In: Verbum Caro. Ensayos teológicos vol. I, p. 195-223, exatamente à p. 211.

${ }^{14}$ Importante deixar claro que aqui não se nega o caráter científico da teologia. O que se recorda é que sem deixar de ser ciência a teologia arranca da Revelação e para ela deve retornar. Sem fé não se pode fazer teologia. Pode-se fazer ciência da religião, mas não teologia propriamente dita. São iluminadoras as palavras de Balthasar: “... e posto que a teologia não pode ser outra coisa que meditação esclarecedora sobre esta confissão de fé, para entende-la e fazê-la compreensível aos outros, só pode fundamentar-se e desenvolver-se apropriadamente no Espírito Santo". Cf. BALTHASAR, Teológica, vol. III, p. 364. Além disso, toda a trilogia de Balthasar com suas mais de 8 mil páginas revela sua hercúlea tentativa de dialogar com o seu tempo, apresentado a Revelação a partir dos transcendentais do Belo, do Bom e do Verdadeiro. Cf. GUERRIERO, Hans Urs Von Balthasar, p. 140.

${ }^{15}$ Apud PALUMBO e AZCUY, Contornos de una figura..., p. 7-23.
} 
Tal afirmação distancia Balthasar da neo-escolástica, da crítica histórica e das teologias contextuais. Por isso, é necessário buscar em Balthasar qual a alternativa que ele oferece para a atividade teológica, a fim de que se possa fazer uma teologia rica e relevante. A resposta virá no binômio teologia-santidade.

\begin{abstract}
A teologia "racional" não começa só com Tomás, [...] teve que ser praticada pelos Padres para a defesa da fé contra as doutrinas errôneas. Tal teologia, que consiste na explicação ordenada da íntima textura da unidade da fé [...] não pode ser outra coisa que uma etapa prévia da teologia orante e confessante $[\ldots]$ enquanto o homem é essencialmente um buscador $[\ldots]$ e há de seguir buscando continuamente ao Deus que o encontra [...], este esforço racional nunca deve ser excluído da teologia mais orante...". ${ }^{16}$
\end{abstract}

Como prolegômeno necessário para a intelecção da obra de Balthasar é preciso ter sempre presente que só o amor é digno de fé. ${ }^{17}$ Este é o título de uma obra sua, que apesar de sucinta, oferece algumas balizas importantes para que se possa fazer uma boa aproximação do pensamento de Balthasar. ${ }^{18}$

\title{
2.2 O uso da Bíblia
}

Nos escritos balthasarianos a Bíblia é usada em abundância. Balthasar seguiu a indicação conciliar (DV 24), fazendo da Escritura a alma de sua teologia. Vale lembrar que Balthasar preferia perscrutar a Bíblia não através da exegese histórico-crítica, que ele conhecia e sabia utilizar, mas levando em conta os quatro sentidos ${ }^{19}$ da Escritura. Através dessa interpretação mística,

\footnotetext{
${ }^{16}$ BALTHASAR, Teológica, vol. III, p. 362.

${ }^{17}$ Acerca do amor, como assunto fundamental de toda obra, Guerriero cita Balthasar: "A palavra de Deus era o amor. Porque quem abre a si mesmo ama participar-se [...] a Palavra de Deus vem do alto. Vem da plenitude do Pai. Nela não havia tensão, porque ela própria era a plenitude. Era luz em si mesma, vida e amor sem desejo, amor que teve compaixão do vazio e decidiu preenche-lo". E explica Guerriero, "O amor, consequentemente, é o principio primeiro, a nascente que alimenta o pensamento e os escritos do teólogo”. Cf. GUERRIERO, Hans Urs Von Balthasar, p. 139.

${ }^{18}$ Outras obras programáticas (que remetem para a trilogia) ou monográficas (que analisam uma figura [santo, místico, poeta...], como um detalhe para se chegar ao todo) que ajudam a compreender melhor o pensamento de Balthasar são: El compromiso cristiano en el mundo de 1981; Nos conoce Jesus? Lo conocemos? De 1980; La verdade del mundo de 1947; Córdula de 1966 dentre outros. Cf. PALUMBO e AZCUY, Contornos de una figura..., p. 7-23.

${ }^{19}$ Um dístico do séc. XIII resume os quatro sentidos da Escritura dessa maneira: Littera gesta docet, quid credas allegoria; moralis quid agas, quo tendas anagogia. "A letra ensina o que
} 
Balthasar buscava a teologia não da doutrina, mas da existência, das pessoas e da história, fugindo de uma teologia bíblica tecida de fórmulas abstratas. Em Derrubar as muralhas (1952), Balthasar reclama do esquecimento dessa interpretação mística:

...a "interpretação mística" da Sagrada Escritura, fundada pelos padres da Igreja e por eles orientada na direção certa (não obstante alguns erros e certa insuficiência técnica), em seguida acabou sendo descuidada até ser, hoje, relegada ao esquecimento. ${ }^{20}$

\subsection{A importância dos Santos Padres}

Outra característica importante da teologia de Balthasar é o seu profundo conhecimento da teologia dos Padres da Igreja. ${ }^{21}$ Foi seu professor Henri de Lubac que lhe mostrou a grandeza da teologia patrística. ${ }^{22}$ Sua reflexão ecle-

aconteceu; a alegoria, o que tens de crer; o sentido moral, o que tens de fazer e o sentido anagógico aquilo para o qual deves tender". Cf. BEAUCHAMP, P. Sentidos da Escritura. In: LACOSTE, J.-Y. (dir.). Dicionário Crítico de Teologia. São Paulo: Loyola, 2004, pp. 1634-1642. ${ }^{20}$ BALTHASAR, H. Derrubar as muralhas, São Paulo: Paulinas, 1971, p. 52.

${ }^{21}$ Por Padre da Igreja se entende aqui um escritor eclesiástico antigo, notável por sua ortodoxia e santidade, reconhecido pela Igreja, pela sua doutrina de fé. Ele cumpre quatro condições: 1 . Doutrina ortodoxa; 2. Santidade de vida; 3. Aprovação eclesiástica; 4. Antiguidade. Cf. MEIS, Anneliese, Hans Urs Von Balthasar y los padres de la Iglesia. In: Proyecto. 1998, 30-33.

22 "A patrística é algo complexo e diversificado, irredutível a um denominador comum. Prolonga-se a era dos Padres da Igreja desde a última década do século I até os meados do século VIII. Nos seus inícios estão os Padres apostólicos, assim chamados porque quase que exclusivamente reproduzem o ensinamento dos Apóstolos, principalmente os de Paulo de Tarso. Por volta do ano 125 surgem os Padres apologistas, comprometidos na defesa da fé cristã diante dos ataques do judaísmo e do paganismo. É em torno do ano 200 que se constitui, na Igreja, o que se poderia chamar de "ciência teológica" propriamente dita, com o advento de pensadores de larga envergadura, como Irineu de Lião, Clemente de Alexandria, Tertuliano e Orígenes. Já no século IV surgem os três grandes Capadócios: Basílio de Cesaréia, Gregório de Nazianzo e Gregório de Nissa. Entre tantos méritos dos Padres, destaca-se o de empreender um esforço não pequeno por pensar a identidade da sociedade que então passa a se caracterizar como cristã. No século IV, tendo sido o cristianismo adotado por Constantino como meio de coesão do Império romano e, mais tarde, reconhecido oficialmente por Teodósio como religião estatal, os seguidores do "Caminho" (At 19,9.23) se vêem livres da perseguição imperial e têm a chance de começar a pensar a Deus num novo contexto social. É nesta nova situação que se introduz o termo "teologia" na acepção que hoje conhecemos, a saber, discurso racional sobre Deus". In.: Editorial. Perspectiva Teológica, Belo Horizonte, vol. 35, no. 97, p. 293-300, set.- dez. 2003. 
siológica está pontuada pela dos santos padres. ${ }^{23}$ Balthasar dedicou ensaios a Orígenes, Gregório de Nissa, o Aeropagita e Irineu. Com e a partir de Agostinho escreveu a sua teologia da história ${ }^{24}$

Balthasar deve aos santos padres sua visão unitária entre teologia e santidade e igualmente a sua orientação teológica prioritariamente simbólico-espiritual. ${ }^{25}$ A Patrística é uma dimensão transversal na volumosa obra de Balthasar. Ele está realmente familiarizado com a teologia fontal que se encontra na Patrística. O que Balthasar aprecia nos santos padres é a relação pessoal e vital que eles mantêm com Jesus Cristo.

Exatamente por isso, eles ousaram pensar a fé em distintos contextos culturais, a fim de que Jesus Cristo fosse anunciado. Para Anneliese Meis, os santos padres elaboraram uma teologia que desconhecia a separação entre a razão pura e a razão prática. ${ }^{26}$ Esta autora também explica que para Balthasar o problema abordado pelos padres é o da inculturação da fé. Com efeito, os padres dialogaram com o mito, a filosofia, a tragédia e a religião de então. Em Balthasar, a sua extensa trilogia é exatamente essa tentativa de diálogo com a cultura da sua época.

A recuperação que Balthasar faz da Patrística não é somente histórica. Ele não quer lembrar somente como foi a teologia dos padres, mas procura mostrar sua relevância para a teologia hoje, seguindo assim os passos de seus mestres De Lubac e Danielou. Balthasar mergulha na história dos padres a fim de descobrir nos fragmentos antigos a totalidade do sentido.

Isso ele fará identificando a relação que os padres têm com Jesus Cristo. Ele é o princípio primeiro e ordenador da realidade. A relação com Cristo dá ao ser humano a vida e revela sua verdade (GS 22). No centro da teologia de cada padre está esta relação mística com Cristo e que constitui a base de cada sistema patrístico. ${ }^{27}$

${ }^{23}$ GUERRIERO, Hans Urs Von Balthasar, p. 50-69. Balthasar irá retirar dos santos padres uma série de temas e de imagens que irá articular em seu discurso eclesiológico. Só para citar algumas: o exemplarismo cristão de Justino, Irineu, Clemente e Origenes. (Exemplarismo que é a doutrina segundo a qual as coisas e os seres do mundo são imagens ou cópias de arquétipos que subsistem na mente divina. É clara a influencia platônica nessa doutrina); A Igreja compreendida como Virgem, Esposa e Mãe; a relação profunda entre Maria e a Igreja; a teologia patrística do ministério radicado na Igreja santa; a sucessão apostólica como continuidade do ministério petrino. Cf. BALDINI, A. principio petrino e principio mariano ne "Il complesso antiromano" di Hans Urs Von Balthasar. Lugano: Eurpress, 2003, p. 103-121.

${ }^{24}$ Ibid., p. 69.

${ }^{25}$ PALUMBO e AZCUY, Contornos de una figura..., p. 7-23.

${ }^{26}$ MEIS, Anneliese. Hans Urs Von Balthasar y los padres de la Iglesia. In: Proyecto. 1998, 30-33.

${ }^{27}$ Ibidem. 
Ao elaborar sua teologia Balthasar deseja abrir a teologia dos padres para todos que desejam conhecê-la mais profundamente. Para A. Meis, Balthasar baseia seu estudo patrístico no axioma que reza que há uma grande desproporção entre a mensagem revelada e a compreensão humana. ${ }^{28}$ Por conta disso, existem diferentes graus de assimilação da teologia patrística, que apesar de difícil é sempre proveitosa.

\subsection{Adrienne e a mistica}

Não se pode esquecer igualmente da influencia de Adrienne von Speyr, que com suas experiências místicas marcará profundamente a teologia de Balthasar. Digno de nota é o fato de Balthasar jamais ter duvidado da inspiração divina de Adrienne, apesar de toda sua erudição teológica e exigência de integridade espiritual. Ele se encontra com ela diariamente sendo seu estenógrafo por 27 anos.

Ele a vê como uma teóloga, nos moldes da Patrística. Diz ele: "Sua obra e a minha não são separáveis, nem psicologicamente, nem filológicamente; são duas metades de um todo que, como centro, tem um único fundamento". ${ }^{29}$ É sabido que Balthasar a acompanhou em seus êxtases místicos e que anotava tudo aquilo que ela experimentava nesses momentos. Há, por exemplo, um comentário ao Evangelho de São João, ditado por Adrienne à Balthasar nos anos de 1944-1946, que tem mais de três mil páginas! Balthasar admitia que Deus pode se comunicar com as pessoas pela união mística, não para anunciar uma nova Revelação, mas para aprofundar aquela que fora trazida por Jesus e revelar aspectos que não têm sido percebidos por uma teologia que não se preocupa mais com a santidade. ${ }^{30}$

\footnotetext{
${ }^{28}$ Ibidem.

${ }^{29}$ Cf. BALTHASAR, Unser Auftrag, 1984. Nesta obra Balthasar apresenta os principais temas de sua teologia que tem uma inspiração Spyeriana a saber: teologia da confissão, Cristologia da obediência, a teologia do sábado santo, o tema eclesiológico do ministério amor.

${ }^{30}$ Diz Balthasar: "Se puede decir que con 'la muerte de los apostoles se ha concluído la Revelación objetiva' aunque se sabe qué limitada es esta expressión. Pues 'concluída' sólo puede significar desde el lado de Dios que Él ha expressado en su Palabra única todo lo que puede decir hasta el final [...], y más allá de esto no queda objetivamente ninguna palabra más por decir, porque la última objeción de lo antidivino ha sido assumida y resuelta por Dios mismo; esto significa que esta palavra extrema hace brotar um manantial de lenguaje que salta hasta lo infinito. Verbum Dei non est alligatum". BALTHASAR, Teodramática, vol. I, p. 71. O itálico é nosso.
} 
Conforme Johannes Schiettecatte, o que Balthasar aprendeu com Speyr foi conceber a existência cristã como uma eleição radical para seguir a Cristo. ${ }^{31}$ Graças às intuições de Adrienne, Balthasar insere o espírito joanino no carisma inaciano. Trata-se da obediência de Inácio enquanto radicada no amor de João por Cristo. A obediência inaciana está impregnada pelo permanecer (no amor de Cristo) joanino. Esta obediência amorosa se concretiza numa dedicação e disponibilidade total para com a Igreja petrina. A Igreja do amor informa e dá sentido à Igreja ministerial. ${ }^{32}$

Scola lembra que Balthasar assumiu a difícil tarefa de verificar a sintonia das intuições místicas de Adrienne com relação à doutrina da Igreja e a grande Tradição teológica. ${ }^{33}$ Não se pode esquecer finalmente, que para muitos é problemática a influencia de Speyr na teologia de Balthasar. Sempre se pergunta de novo: Poderá a experiência mística despertar novos horizontes e caminhos para a reflexão teológica? ${ }^{34}$ Não será esse expediente, como já se acusou Balthasar, uma espécie de gnose que só alguns tem acesso privilegiado? Parece não ser esse o caso, pois se vê tanto nos escritos, quanto na vida de Balthasar, o desejo de ampliar e difundir o conhecimento obtido pela via mística de Adrienne, desde que sempre conferido e referendado pela Tradição eclesial. Segundo Balthasar, na mística aparece a unidade vital entre teologia e santidade, pois a santidade vivida na Igreja tem implicações doutrinais. Para ele os autênticos místicos tem uma riqueza doutrinal que não tem sido adequadamente considerada pelas escolas teológicas. ${ }^{35}$

${ }^{31}$ SCHIETTECATTE, J. Hans Urs Von Balthasar y Adrienne Von Speyr. In: Proyecto. 1998, 34-38.

${ }^{32}$ Ibidem.

${ }^{33}$ SCOLA, A. Hans Urs Von Balthasar: um estilo teológico. Madrid: Encuentro, 1997, p. 26.

${ }^{34}$ PALUMBO e AZCUY, Contornos de una figura..., p 7-23. Assim explica Lehay a mística em Balthasar: "Em seus escritos ele apresenta a mística como momento profético da vida da Igreja na qual uma pessoa individual se vê dotada de uma intuição particular do Evangelho válida para toda a Igreja: este dom deve ser vivido com uma anima eclesiastica mariana. $\mathrm{Na}$ mística existe um duplo momento: um primeiro momento de solidão, no qual a alma se sente impulsionada ao interior do seio do Pai, em uma cascata de graças; um segundo momento de comunhão com todos, no qual a alma se sente dirigida a comunidade na perspectiva de edificar a comunhão graças a nova interpretação da Revelação que lhe foi oferecida. Von Balthasar considera a mística como um movimento eminentemente mariano: é expressão da receptividade de Maria que continua na realidade eclesial como associada ao Verbo e ícone da Igreja”. LEAHY, B., El principio mariano..., p. 159.

${ }^{35}$ BALTHASAR, H. Teologia y santidad. In: Verbum Caro, Ensayos I, p. 195-223. 


\subsection{A amizade com Barth e a questão da santidade}

Há também a significativa influência do grande teólogo calvinista Karl Barth na teologia de Balthasar. Isso transparece em seus escritos sobre a Igreja (Sponsa Verbi) e sobre a história (Theologie der Geschichte), por exemplo. ${ }^{36}$ Apesar disso, Balthasar não elaborou uma teologia parcial, mas sempre foi um tenaz defensor da Tradição católica.

Segundo Fisichella, que fornece as diretrizes para a análise aqui apresentada, a teologia de Balthasar é “... fascinante e sedutora, [...] é difícil. Poesia, teatro, música, arte, filosofia formam, em razão da Escritura lida na tradição dos Padres, dos mestres teólogos e dos santos, um conjunto único, que sabe garantir uma palavra de esperança [...] em relação ao amor gratuito e misericordioso de Deus". ${ }^{37}$

Finalmente, vale lembrar que Balthasar mais do que escrever teologia desejava viver a santidade, pois para ele o compromisso do cristão com o mundo não se reduz a uma abstrata atividade teológica, pois na vida dos santos a teologia vivida e não a teologia escrita sempre teve a primazia.

Como centro existe um interesse completamente distinto: o trabalho pela renovação da Igreja com a formação de comunidades que unam os conselhos evangélicos de Jesus com a vida em meio ao mundo, seja exercendo profissões profanas, seja no sacerdócio ministerial, para dar nova vida as comunidades viventes. Toda a atividade de escritor está subordinada a este trabalho, se o escritor tivesse que diminuir pela urgência do trabalho de que falei, a mim não pareceria que perdesse algo, mas sim que tivesse ganhado muito. No fundo isso é evidente para quem que esteja a serviço da causa de Jesus que, concretamente, é a Igreja. ${ }^{38}$

\footnotetext{
${ }^{36}$ FISICHELLA. Balthasar, pp. 231-237.

${ }^{37}$ Ibidem.

${ }^{38}$ BALTHASAR, My work in retrospect, San Francisco: Ignatius press, 1993, p. 95. De qualquer forma, vale lembrar que Balthasar, "produziu 119 obras monográficas, 532 artigos de diversas qualificações, 114 ensaios de comentários, 110 traduções, 29 estudos antológicos, 103 introduções a diversas obras, 93 recensões e 13 trabalhos editoriais, num total de 1113 títulos. [Apenas para que se tenha uma idéia] sua trilogia tem cerca de 8 mil páginas!". Cf. SILVA, José Pereira da. Hans Urs Von Balthasar: Teólogo do essencial. Atualização. Belo Horizonte, no. 314. p. 233-250, mai-jun. 2005.
} 


\section{A trilogia do amor ${ }^{39}$}

A elaboração deste tríptico consumiu os últimos 25 anos da vida de Balthasar (1961-1987). A Trilogia é composta por uma Estética teológica ou Teo-estética em 7 volumes (1961-1069), seguida de uma Teo-dramática em 5 volumes (1973-1983) e encerrada por uma Teo-lógica em 3 volumes (19851987), coroados pelo Epílogo de 1987. Balthasar estrutura sua trilogia segundo a ordem teológica que surge da Revelação: primeiro Deus se mostra (Encarnação), em seguida se doa (Cruz) e finalmente se diz (Pentecostes).

Deus vem primariamente a nós não como mestre (verdadeiro), nem como redentor (bom), mas para mostrar e irradiar Ele mesmo, a glória de seu eterno amor trinitário, com aquela ausência de interesse que o verdadeiro amor tem com a verdadeira beleza. $\mathrm{O}$ mundo, com sua própria glória foi criado para glória de Deus e também será salvo para a glória de Deus. ${ }^{40}$

O objetivo da trilogia é mostrar que o centro da Revelação é a única realidade que possui plenitude de sentido. Com ela, Balthasar quer oferecer a seus contemporâneos as "razões da esperança cristã" $(1 \mathrm{Pd} 3,15)$ para que dessa forma, a mensagem cristã seja crível e aceitável para o mundo. Na primeira parte tudo é visto à luz da beleza da Revelação que atrai e arrebata; Na segunda, o drama se coloca em torno do confronto entre a liberdade divina e a liberdade humana, sobretudo com relação ao bem e ao mal; Finalmente, Balthasar trabalha o conceito da verdade e da sua relação com o Espírito Santo e o mundo.

A originalidade desta obra se funda na eleição dos transcendentais do ser como eixo articulador do método teológico e está explicada pelo autor

\footnotetext{
39 Guerriero apresenta uma bela e estimulante síntese da trilogia de Balthasar. Lembra principalmente que Balthasar renunciou a dar um título a sua obra exatamente para não dar a idéia de uma construção teológica ordenada e monolítica. Deficiência desse enfoque são as frequentes repetições nas diferentes partes da trilogia. Mas também, em função dessa liberdade de estilo, Balthasar pode dar espaço para a literatura e a filosofia. Guerriero conclui dizendo que, “... a trilogia de Von Balthasar vai além de uma obra estritamente teológica. Ela é um simpósio de literatura, filosofia e teologia, chamadas a perceber e a dar testemunho do amor de Deus que se revela. É esse o seu fascínio e a sua fecundidade, esse o seu limite para quem deseja uma construção teológica direcionada e irrefutável”. Cf. GUERRIERO, Hans Urs Von Balthasar, p. 139-163.

${ }^{40}$ BALTHASAR, My work in retrospect, San Francisco: Ignatius press, 1993, p. 80. Neste livro estão reunidos os cinco textos que Balthasar escreveu de $10 \mathrm{em} 10$ anos, a partir de 1945, como um balanço de sua obra teológica.
} 
de modo sintético em uma das passagens mais perfeitas do Epílogo “... mostrar-se (belo) - dar-se (bom) - dizer-se (verdadeiro) eram diferentes aspectos deste manifestar-se (...) a essência se apresenta em sua manifestação, esta apresentação lhe dá uma figura no mundo, na qual se pode colocar seu conteúdo de sentido (seu logos) como algo perceptível em sua unidade; deste modo, a essência também entra em conexão com o mundo, de tal maneira que possa ser empregada como dom (uti) e também desfrutada (frui), provando assim, finalmente sua verdade".(E 64) Dito mais teologicamente e para sublinhar a unidade entre mostrar-se, dar-se e dizer-se: "A Glória de Deus é sua auto-entrega e esta é, por sua vez, sua verdade". (E 66)

\subsection{A Estética}

Muitos consideram Balthasar um mero esteta. Dele se lembram somente por esta primeira parte da sua trilogia. Desse fato o próprio Balthasar tinha consciência. ${ }^{42}$ Contudo, não se pode isolar a estética do conjunto da sua obra. Trata-se do primeiro passo na apresentação global do mistério divino. Em Balthasar, a Revelação que se manifesta inicialmente no belo, precisa ser integrada ao bom e ao verdadeiro ${ }^{43}$

$\mathrm{Na}$ estética, Balthasar estuda o belo na perspectiva da kabod bíblica e da doxa joanina. Aqui a Glória é a irradiação do ser. Ela é gratuidade e transcendência, é a manifestação primeira de Deus para o mundo. Tal glória alcança a sua plenitude em Jesus Cristo, forma da nova e eterna aliança entre Deus e a humanidade. Somente um olhar banhado pela fé poderá repetir a mesma experiência que fizeram os primeiros discípulos do Senhor. ${ }^{44}$

Fisichella explica que se pode ler a estética a partir da distinção entre a percepção da glória e o arrebatamento que lhe sucede. Na doutrina da percepção se estuda o duplo movimento (objetivo e subjetivo) que evidencia a Revelação. Do lado objetivo se dá a aparição do fenômeno que carrega consigo a

\footnotetext{
${ }^{41}$ PALUMBO e AZCUY, Contornos de una figura..., p. 7-23. Onde a abreviação E = Epílogo.

${ }^{42}$ BALTHASAR, My work in retrospect, San Francisco: Ignatius press, 1993, p. 96.

${ }^{43}$ BALTHASAR, My work in retrospect, San Francisco: Ignatius press, 1993, p. 96-99. Veja também: PALUMBO e AZCUY, Contornos de una figura..., p. 7-23.

44 "Los apostoles son arrebatados por aquello que vem, oyen e palpan, por aquello que se revela en la forma; Juan (sobre todo, pero también los demás) describe continuamente cómo em el encuentro, en el diálogo, se destaca la forma de Jesus y se dibujan sus contornos de manera inconfundible, y cómo de repente, de un modo indescritbile, surge el rayo de lo incondicionado y derriba al hombre, haciendole caer prostrado en adoración, transformandolo en un creyente y seguidor de Cristo". BALTHASAR, Hans Urs von. Glória. Vol. I, p. 34-35.
} 
essência e a existência; já do lado subjetivo, tal fenômeno é conhecido pela fé. De que fenômeno se fala aqui? Segundo Balthasar, se trata da Gestalt (forma) de Deus. É a expressão do absoluto que remete a sua profundeza constitutiva. Aqui o conteúdo é idêntico à figura que o exprime. Fica fácil perceber que para Balthasar Jesus é a Gestalt de Deus (Ele é a imagem do Deus invisível). $\mathrm{O}$ fiel percebe Jesus como Deus encarnado. Como se viu acima, o momento subjetivo é marcado pela fé. Ela torna o ser humano capaz de conhecer adequadamente a Gestalt divina que Jesus manifesta. Assim, à riqueza da Gestalt deve corresponder a fé, pois só ela pode acolher tal fenômeno adequadamente. Voltando para Fisichella, "o que é dado teologicamente é a primazia de um fides quae que faz compreender a fides qua como ato cujo conteúdo é já, nele mesmo, rico da plenitude do mistério". ${ }^{45}$

Quanto ao arrebatamento, esse êxtase se dá na medida em que o ser humano se abre para uma admiração sempre maior diante do mistério divino. Aqui o eu se deixa envolver pela Gestalt, numa participação pessoal no mistério da vida divina, que leva o fiel a se abandonar totalmente no mistério divino. Nessa ideia de abandono se percebe a influencia de Eckhart, Heidegger e especialmente de Santo Inácio e seu conceito de obediência total.

Para Balthasar, quem deseja experimentar a Revelação divina deve percorrer o caminho da sua figura global que Jesus, Deus encarnado, desvela a humanidade. Assim, Balthasar une a Revelação histórica de Jesus, entendido como o centro da Revelação, com sua continuação histórica mediante a Igreja, lugar em que se dá todo ato de fé autêntico. ${ }^{46}$

Diz Fisichella que:

Pode-se perceber nesse contexto a especificidade da Cristologia de Balthasar, tal como se exprime na categoria de obediência e encontra seu ponto culminante na kenose, compreendida de maneira joanina como glória e amor. [...] O amor é condição de possibilidade de toda ação trinitária [...] ele não é medido pelo padrão do amor humano, é determinado somente pela livre iniciativa de Deus. Essa análise permite a Balthasar não cair nas representações cristológicas já determinadas pela antropologia.[...] a Igreja é analisada do mesmo modo nos escritos de Balthasar [...] compreendida como "corpo" de Cristo, e sobretudo como sua "esposa", condensa em si mesmo a complexidade do mistério: é ao mesmo tempo uma realidade que depende

\footnotetext{
${ }^{45}$ FISICHELLA. Balthasar, pp. 231-237.

${ }^{46}$ Ibidem.
} 
de sua "cabeça" e uma pessoa livre e capaz de escolher. A Igreja exprime a lógica da mediação revelada centralmente em Cristo, e que convida a compreender a fé, simultaneamente, como ato humano e como ato divino. Ela é, com efeito, a Igreja mariana, e, portanto, puro fiat de obediência em relação ao seu Senhor, mas é também a Igreja de Pedro e, portanto, ministério em vista do desenvolvimento da comunidade. Assim é possível construir uma Eclesiologia que repouse, de um lado, no acolhimento da gratuidade da graça (Maria) e de outro lado, na decisão e na ação concretas (Pedro). ${ }^{47}$

\subsection{Dramática teológica}

A dramática une a beleza à verdade. Entre o ver e o dizer, está o fazer bem todas as coisas. A teodramática é o núcleo da trilogia. A teofania vista na estética não se reduz a uma mera contemplação. Nessa manifestação já começa a ação de Deus no mundo como um Teo-drama. É somente diante dessa ação divina na história que o ser humano será capaz de pensar uma Teo-logica. ${ }^{48} \mathrm{~A}$ imagem do teatro do mundo ${ }^{49}$, Balthasar parece ter tomado emprestado de Pedro Calderón de la Barca $^{50}$ (cuja obra o próprio Balthasar traduziu para o

\footnotetext{
${ }^{47}$ FISICHELLA. Balthasar, pp. 231-237. Grifo nosso.

48 "La revelación de Dios Teo-estética no es ningún objeto para mirar, sino que es su própria acción en y para él mundo Teo-dramática, la cual puede ser respondida, y así 'comprendida' Teo-logica, por el mundo mediante su acción”. Cf. BALTHASAR, Glória Vol. I. p. 19. E também: "La gloria de Dios que hace sua aparición en el mundo y que alcanza su centro en Cristo no es algo estático que se pueda contemplar de modo neutral. Se hace más manifiesta sólo en un compromisso dispuesto a la lucha, con sus victorias y sus derrotas, y reclama un compromisso análogo para que entre en el próprio ángulo de mira. La revelación es un campo de batalla”. BALTHASAR, Teodramática. Vol. IV. Madrid: Encuentro, 1995, p.16.

${ }^{49}$ Confira o extenso trabalho realizado por Balthasar a respeito da história da categoria teatro do mundo em BALTHASAR, Teodramática, vol. I, p. 129-250.

${ }^{50}$ Calderón, foi um dramaturgo e sacerdote católico que nasceu em Madri no dia 17 de janeiro de 1600. Perdeu seus pais na infância e foram fundamentais para a sua formação os anos de estudo junto aos jesuítas no colégio imperial. Estudou também nas universidades de Acalá e de Salamanca onde aprendeu a lógica, o teatro, a persuasão, a história profana e canônica e o direito natural que usou na sua criação literária. Ele escreveu comédias, dramas e tragédias. Toda sua obra literária busca dar repostas ao difícil contexto social e cultural de sua época. Sua dramaturgia é vista como de vanguarda para o mundo do teatro. Entre 1630 e 1640 ele começa a compor autos sacramentais, que tem especialmente uma preocupação ética. Provavelmente nessa época ele escreveu $O$ grande teatro do mundo. No final da sua vida se dedicará quase que exclusivamente ao teatro sacro. Entretanto ele também escreveu muitas peças breves e irreverentes. Calderón morreu em 1681 enquanto escrevia autos para a festa de Corpus Christi daquele ano. Ele representou o cume das artes cênicas da sua época. Sua obra que nasceu sob o signo da crise com a modernidade ainda mantém a emocionante e vigorosa contemporaneidade de um clássico.
} 
alemão em $1959^{51}$ ). Por exemplo, olhando para a Trindade nessa perspectiva se entende que o Pai é o autor, o Espírito, o diretor e Cristo, o ator principal. A categoria dramática do papel teatral é transposta para a teologia através do conceito de missão. Cada ser humano tem uma missão que está visceralmente ligada à Cristo pela aceitação ou pelo rechaço. Nesta parte da obra de Balthasar se dá o encontro entre a doação pura e gratuita de Deus de um lado, e a resposta livre e responsável do ser humano, do outro. Fisichella explica que,

"dramática" aqui é tomada em sentido próximo do sentido teatral: trata-se dessa dinâmica pela qual o publico e o ator defrontam-se, pela qual o espectador poder perceber-se a si mesmo como co-ator, porque está imerso no cerne da lógica representativa, e pela qual enfim nos encontramos implicados, radicalmente, nas questões que comprometem não um momento da vida, mas a existência como tal". ${ }^{52}$

Segundo o mesmo autor, a natureza da teologia requer uma narrativa dramática, pois seu objeto é a dramática relação entre Deus e a humanidade. Através dessa narrativa, a existência pode ser pensada à luz de um papel e de uma missão, o que ajuda a superar a ideia de que o ser humano seria fruto do acaso. Ao reconhecer a missão recebida, o ser humano constrói a trama da sua existência que só poderá chegar à sua plenitude se for compreendida à luz da missão de Jesus e da sua existência obediente ao Pai.

$\mathrm{Na}$ dramática aparece a antropologia balthasariana que não repousa na subjetividade humana, mas sempre na objetividade da Gestalt Christi, pois só ela pode dar conta do sujeito humano. O drama parte sempre do compromisso de Deus para com a humanidade e do Seu agir para honrar esse compromisso.

Balthasar parte da teologia da Encarnação, pois nela se concretiza uma relação entre Deus e o homem, onde o ser humano se torna co-ator. Ele apresenta dois temas básicos: a formulação do papel (missão) e a relação entre liberdade divina e a liberdade humana. No primeiro, o ser humano se descobre como parceiro de Deus numa ação dramática. Já no segundo, se pode prever o desenrolar do teo-drama.

Cf. <http://bib.cervantesvirtual.com/bib_autor/Calderon/autor.shtml>, acessado dia 13/09/2011 às 17h00min. Existe uma versão eletrônica desta obra de Calderón "El grande teatro del mundo" em: <http://bib.cervantesvirtual.com/servlet/SirveObras/01715852871255926328813/p0000001. htm\#I_0_> , acessado dia 13/09/2011.

${ }^{51}$ BARCA, Calderón de la. Das grosse Weltheater. Einsiedeln: Johannesverlag, 1959.

${ }^{52}$ FISICHELLA. Balthasar, pp. 231-237. 
$\mathrm{Na}$ antropologia de Balthasar só é capaz de responder a pergunta sobre seu ser e sua missão, a pessoa que se identifica, pelo menos em parte, com um papel. No horizonte da Bíblia (os patriarcas, os profetas, Jesus e seus discípulos), o ser humano se entende como alguém que tem uma missão nessa vida. Aqui se insere a discussão sobre a liberdade. "Por ser criada, a liberdade pessoal produz uma experiência dramática: em razão de nossas decisões, o 'ser-em-direção-ao-outro' pode se tornar um 'ser-para-o-outro' ou então um 'ser-contra-o-outro'. Por conseguinte, a liberdade do sujeito não começa com o confronto com outra liberdade finita, mas antes pela abertura imediata a uma liberdade absoluta". ${ }^{53} \mathrm{O}$ ser humano se compreende sempre como alguém que é livre na medida em que caminha para essa liberdade.

Balthasar usa a expressão bíblica imago Dei para responder a pergunta pelo humano. Ela é a expressão mais completa, pois se liga ao ato criador de Deus. Segundo Fisichella, neste ponto Balthasar é claramente seguidor de Irineu de Lião ${ }^{54}$.

A dramática também apresenta a cruz como sinal do amor trinitário. Nela Deus se manifesta em sua natureza íntima de ser um Deus que vai para a morte por ser um Deus que ama. A dor, o sofrimento, a cruz e a morte são expressões limites, mostrando até onde Deus pode ir com seu amor. A cruz para Balthasar, não tem só um valor soteriológico, mas só ela é capaz de manifestar concretamente a ação de Deus. Na vida de Jesus há um kenose progressiva, desde a sua Encarnação: primeiro Ele se esvazia da glória divina, em seguida assume a carne humana e finalmente encontra a morte e o túmulo. Toda essa interpretação demonstra a influencia de Adrienne na teologia de Balthasar. ${ }^{55}$

Balthasar entende por kenose aquilo que é transmitido no hino cristológico presente em Fl 2,6-11 ${ }^{56}$. Nesse hino se coloca em evidencia a origem

\footnotetext{
${ }^{53}$ Ibidem.

${ }^{54}$ Para quem deseja mais detalhes sobre o pensamento antropológico de Irineu cf. ORBE, Antonio. Antropología de San Ireneo, Madrid: BAC, 1969.

${ }^{55}$ Nesse sentido, Angelo Scola diz que Balthasar ao, “...haberse puesto al servicio de Adrienne significo también para él recoger de ella sus no pocas intuiciones singulares acerca de algunos misterios de nuestra fé. Y asumió la difícil tarea de verificar su sintonia respecto de la doctrina de la Iglesia y la gran tradición teológica. No solo la célebre doctrina sobre el infierno y el 'esperar para todos', sino también la teologia del Triduo pascal y aspectos no secundarios de su reflexión cristológica y trinitaria han tenido em Adrienne más que uma precisa fuente de inspiración". Cf. Hans Urs Von Balthasar: um estilo teológico. Madrid: Encuentro, 1997, p. 26. Cf. BALTHASAR, H. Mysterium Salutis III/6 - Mysterium Paschale. Petrópolis: Vozes, 1974. Onde Balthasar apresenta sua teologia da semana santa especialmente da Sexta, do Sábado e do Domingo.

56 "Ele, estando na forma de Deus não usou de seu direito de ser tratado como um deus, mas se
} 
intra-trinitária desse movimento quenótico. É um movimento eterno de abandono fundado na obediência do Filho. No entanto, foi o Pai que cumpriu uma primeira e originária kenose na geração do Filho: "Livremente, mas radicalmente, Ele (o Pai) se esvazia da sua divindade e a cede integralmente ao Filho. Assim se esclarece o sentido das palavras de Jesus que exprimem a consciência de sua relação com o Pai". ${ }^{57}$

O mesmo dom total e livre manifesta-se também no Espírito. Balthasar se esforça para, por meio desse movimento de auto-despossessão fundado no amor, basear na Trindade imanente cada uma das separações que irão ser percebidas na Trindade econômica. Assim, o abandono do Filho na cruz só é possível, pois está inserido nessa auto-despossessão originária que se dá no seio da Trindade. A cruz é, em termos humanos, aquilo que acontece no interior da Trindade: $o$ ato do dom absoluto e total do amor. Ela deve ser entendida como obediência à vontade do Pai e ao Espírito que faz da morte de cruz uma morte em nome do amor, visto como abandonar-se nas mãos da Deus: "Pai, em tuas mãos entrego o meu espírito" (Lc 23,46).

A cruz é, portanto, um acontecimento trinitário. Toda a Trindade está comprometida. Toda a Revelação divina tende para esse ponto crucial. Nessa morte a salvação é revelada através do sofrimento do inocente por toda a humanidade. Ao mesmo tempo em que a cruz deve ser vista como uma atitude de amor da parte de Deus, ela pode ser vista como uma recusa do amor da parte da humanidade.

Aparece nesse contexto o tema da substituição vicária que evidencia a “onipotente impotência do amor de Deus". Segundo explica Fisichella na leitura que faz de Balthasar, Jesus, "morre na cruz para que ninguém depois dele possa morrer com a aprovação de Deus". ${ }^{58}$

Ele diz ainda que,

O amor trinitário de Deus na cruz não é [...] o empobrecimento de todo amor. Ao contrário: esse momento revela precisamente a essência mesma

\footnotetext{
despojou, tomando a forma de escravo. Tornando-se semelhante aos homens e reconhecido em seu aspecto apenas como um homem abaixou-se, tornando-se obediente até a morte, à morte de cruz. Por isso Deus soberanamente o elevou e lhe conferiu o nome que está acima de todo nome, a fim de que ao nome de Jesus todo joelho se dobre nos céus, sobre a terra e sob a terra, e que toda língua proclame que o Senhor é Jesus Cristo para a glória de Deus Pai”. Bíblia de Jerusalém. São Paulo: Paulus, 2002.

${ }^{57}$ FISICHELLA. Balthasar, pp. 231-237.

${ }^{58}$ Ibidem.
} 
de Deus: permite, com efeito, compreender efetivamente o que significa amar "até o extremo" (Jo 13,1). Se a morte constitui para o homem o limite além do qual já não é possível ir, e se o sofrimento do inocente nos faz contemporâneos da dúvida de Dostoievski, e pode conduzir a gritar que é um escândalo, quando se trata do amor de Deus, então se deve afirmar, igualmente, que Deus não ficou à parte desse escândalo e desse limite. Ao contrário, ele os assumiu em si mesmo: é somente assim que poderiam ser definitivamente vencidos, e que se pode perceber que tem um sentido ${ }^{59}$

\subsection{A lógica teológica}

Esta parte da obra balthasariana se ocupa com a relação que existe entre a verdade divina e a verdade criada. Só se pode chegar a ela depois de ser arrebatado pela figura e se experimentar o drama da liberdade. Não se trata de uma verdade racional e estática, mas existencial e que se realiza no encontro amoroso e livre entre o objeto e o sujeito. Em Balthasar filosofia e teologia estão intimamente ligadas. ${ }^{60}$ Filosoficamente a pergunta seria: A realidade criada é capaz de conter e exprimir a verdade da Revelação? Nos três livros que formam essa parte, Balthasar tenta exprimir o mistério fundamental da fé cristã, que pode ser entendido na seguinte pergunta: como é ontologicamente possível que um logos humano possa ter em si um logos divino? No centro da lógica teológica está o logos, entendido a partir do horizonte joanino, como aletheia. Com efeito, Jesus é o exegeta do Pai, mas é o Espírito que abre os olhos dos crentes para que possam perceber a verdade em sua totalidade (Jo 16, 5-15) ${ }^{61}$

À clássica pergunta sobre a verdade, uma simples resposta metafísica se mostra insuficiente. Para Balthasar a verdade é o desvelamento do ser, que é por natureza, oferenda. Percebe-se que Balthasar une ao conceito de verum as múltiplas conotações do termo bíblico 'émét. ${ }^{62}$

\footnotetext{
${ }^{59}$ Ibidem.

${ }^{60}$ Segundo Balthasar não há teologia sem filosofia, mas ele recorda igualmente que existe em toda filosofia um apriori teológico. Cf. PALUMBO e AZCUY, Contornos de una figura... As autoras lembram também que a relação filosofia-teologia se sustenta sobre a base da Encarnação, pois nela se inclui o cosmos e o ser humano que são fonte de toda filosofia.

${ }^{61}$ Perícope sobre a vinda do Paráclito onde se pode ler no versículo 13: "Quando vier o Espírito da Verdade, ele vos conduzirá a verdade plena, pois não falará de si mesmo, mas dirá tudo o que tiver ouvido e vos anunciará as coisas futuras".

${ }^{62}$ Em grego, verdade se diz aletheia, que significa 'não oculto', 'não-escondido', 'não-dissimulado'. Em latim se diz veritas e se refere à precisão, rigor e exatidão de um relato no qual se diz com detalhes o que aconteceu. Em hebraico se diz emet e envolve a idéia de formação do caráter
} 
A verdade em Balthasar aponta para o mistério do Ser e dos seres. Tal mistério não é compreendido como uma realidade incompreensível apesar de ser infinito. Ele pode ser experimentado e se manifesta por meio da palavra e da imagem. Pela palavra o mistério se manifesta no diálogo entre o eu e o tu; pela imagem, o mistério se manifesta no começo do encontro entre o sujeito e o objeto.

A verdade lida à luz do mistério se revela também como liberdade. Ela se dá num movimento dinâmico e dialético de desvelamento e dissimulação. Só se pode chegar à verdade na medida em que a essência é revelada em sua natureza mistérica.

$\mathrm{Na}$ análise de Balthasar, a verdade adquire seu pleno sentido enquanto aletheia: é a Revelação simples, a manifestação pura do ser, que escapa a todas as sistematizações e que se exprime radicalmente como amor. Se a verdade é Revelação do Ser, seu conhecimento não provém do sujeito, mas antes, do Ser que decide livremente revelar-se na existência. Para Balthasar o conteúdo da verdade não pode ser definido pela racionalidade humana. Sua natureza supera a existência histórica. Aqui a única lógica possível é a lógica do amor, pois ela não violenta o mistério, mas o acolhe e permite seu desvelamento.

\section{Conclusão}

Estudar a teologia de Balthasar é sempre um desafio enriquecedor. $\mathrm{Na}$ trama das palavras está inserida uma teologia bela e profundamente interessada em dialogar. Balthasar tem algo a dizer aos teólogos de hoje. Ao lado da dedicação e do esforço intelectual, não se pode descuidar da vida espiritual. Trata-se da busca da santidade que, longe de uma piedade estéril e descompromissada, é para Balthasar, a vivência dos conselhos evangélicos, que faz dos cristãos: sal da terra e luz do mundo. Sem a santidade, traduzida no seguimento cotidiano, como poderá o cristão dar as razões da própria fé? No fundo parece palpitar a questão: "Para quê? e Para quem fazer teologia? Segundo Balthasar, a teologia é dom de Deus e tarefa humana. Cabe ao teólogo custodiar este dom, construindo com suas palavras, maneiras cada

\footnotetext{
pessoal e de restauração do mundo. Cf. <http://www.hebrew4christians.com/Glossary/Word_of_ the_Week/Archived/Emet/emet.html>, acessado dia 12/10/2010. Para alguns autores o conceito de verdade em hebraico está ligado a palavra emunah que significa confiança. Cf. PEREIRA, Renato M. A concepção semântica da verdade e a teoria da verdade como correspondência. In: Redes - Revista capixaba de filosofia e teologia. Vitória-ES, a. 8 - n. 14, jan.-jun. 2010, p. 45-78.
} 
vez mais acessíveis de levar as pessoas ao encontro com a beleza de Deus, que não só encanta, mas compromete de um modo dramático, a liberdade do ser humano.

\section{Referências Bibliográficas}

BALTHASAR, Hans Urs Von. Teodramática vol. III, Madrid: Ed. Encuentro, 1993.

, Teodramática vol. IV, Madrid: Ed. Encuentro, 1993.

, Espíritu e institución - Ensayos teológicos vol. IV, Madrid:

Ed. Encuentro, 2001

, Sponsa Verbi - Ensayos Teológicos vol. II, Madrid: Ed.

Encuentro, 2001.

,El complejo antiromano, Madrid: BAC, 1981.

, Derrubar as muralhas, São Paulo: Paulinas, 1971.

, Glória vol. I, Madrid: Ed. Encuentro, 1997.

, Teológica vol. I, Madrid: Ed. Encuentro, 1997.

, Epílogo, Madrid: Encuentro, 1998.

, Verbum Caro - Ensayos teológicos vol. I, Madrid: Ed.

Encuentro, 2001.

, Spiritus creator - Ensayos teológicos vol. III, Madrid: Ed.

Encuentro, 2001.

, Só o amor é digno de fé, Lisboa: Assírio \& Alvim, 2009.

, Examinadlo todo y quedaos com lo Bueno. Entrevista de Angelo Scola, Madrid: Encuentro, 2007.

, My work in retrospect, San Francisco: Ignatius press, 1993.

, The Theology of Karl Barth, San Francisco: Ignatius press,

1992.

, Católico. Aspectos del Misterio. Madrid: Ed. Encuentro,

1988. 
BALTHASAR, Hans Urs Von e RATZINGER, J. Maria, primeira Igreja. Coimbra: Gráfica de Coimbra 2, 2004.

BALDINI, Antonio. Principio petrino e principio mariano ne "Il complesso antiromano" di Hans Urs Von Balthasar. Lugano: Eurpress, 2003.

Bíblia de Jerusalém. São Paulo: Paulus, 2002

GUERRIERO, Elio. Hans Urs Von Balthasar. São Paulo: Loyola, 2010.

LACOSTE, J.-Y. (dir.). Dicionário Crítico de Teologia. São Paulo: Loyola, 2004.

LEAHY, Brendan. El principio mariano en la Eclesiologia de H. U. Von Balthasar, Madrid: Ciudade Nueva, 2002.

MARINI, Vittorina. Maria nel mistero di Cristo nella teologia di H. U. Von Balthasar, Roma: Pontifícia Universitá Lateranense, 2004.

MONGRAIN, Kevin. The systematic thought of Hans Urs Von Balthasar. New York: Herder \& Herder, 2002.

NICHOLS, Aidan. Divine Fruitfulness. Balthasar's Theology beyond the Trilogy London: Continuum publishing, 2007

PALUMBO, Cecilia A. La literatura en la estética de Hans Urs Von Balthasar. Salamanca: Secretariado Trinitariano, 2002.

PROYECTO. Homenaje a Hans Urs Von Balthasar. Buenos Aires: s/ed, Ano X, no. 30, [mai.-ago.], 1998. Edição especial.

SCOLA, Angelo. Hans Urs Von Balthasar - Un Estilo Teológico. Madrid: Ed. Encuentro, 1997.

\section{Renato Vieira}

Padre palotino, mestre em teologia pela PUC/SP Atualmente pároco na Paróquia São João Batista, São Paulo/SP E-mail: pe.vieira@ig.com.br

Artigo Recebido em 18/02/2012 Artigo Aprovado em 17/05/2012 